\title{
GOING BEYOND: EFFECTIVE INFORMATION TECHNOLOGY GOVERNANCE ACROSS ORGANIZATIONAL LEVELS
}

\author{
Ezmolda Barolli ${ }^{1}$, Ilir Kurti ${ }^{2}$
}

\begin{abstract}
Although information technology today is a driving force behind public sector innovation, harnessing the benefits of investing in such technology is challenging for governments worldwide. Hence, a wide number of governments are endeavoring to implement governance projects for effective information technology. This study expands on earlier research into information technology governance within the public sector. The earlier study proposed a new construct to analyze the critical success factors. While the previous work mainly focused on the strategic level, this current study spans the organizational levels of strategic, tactical, and operational. Apart from a general consensus on Critical Success Factors, the results reveal a number of differences between the levels that affect every organization. Failure to minimize these differences could have a negative effect on the aligning business with information technology.
\end{abstract}

JEL Classification Numbers: M15, G30; DOI: http://dx.doi.org/10.12955/cbup.v6.1129

Keywords: IT governance, critical success factor, organizational levels

\section{Introduction}

Information technology has played an increasingly important role in helping organizations achieve their objectives. While in the past, chief executive officers could avoid decisions relating to information technology (IT), today such an approach is impracticable in most sectors and industries (Peterson, 2004; Van der Zee \& Jong, 1999; ITGI, 2003). Both the public and private sectors have recognized the potential of IT to fuel their innovative initiatives (Potnis, 2010; Luftman \& Ben-Zvi, 2011). As the use of IT becomes more pervasive in the public sector, governments are facing challenges in realizing profits from technological innovations. An important prerequisite to this is that IT complements or supports the work of institutions. It is clear that technology itself has no inherent value and IT alone is unlikely to yield the desired profits or outcomes (Powell \& Dent-Micallef, 1997; Peppard \& Ward, 2004). Thus, governments need better ways to understand, plan, and actively manage IT to harvest its complete value and transformative effects with governments focusing more of their efforts on IT governance (Helbig et al., 2009).

The public sector is complex. The synergies of both individual and inter-institutional institutions characterize its effectiveness. Consequently, the public sector requires strategy, collaboration, and effective accountability from all stakeholders (Weill \& Ross, 2004). Problems related to IT governance in the public sector range from planning and organization to purchase and implementation of maintenance, monitoring, and evaluation of IT (Yahya, 1993; Ndou, 2004; Bakari, 2007). Successful IT integration in such environments requires effective IT governance to supervise the entire lifecycle of the IT and eventually to contribute to the public services that meet the growing demands of stakeholders (Duffy, 2002a; Guldentops, 2004a; Nfuka, 2012).

The governance of IT has been a subject of numerous studies, mainly in developed countries (Nickels, 2004; Brown \& Grant, 2005; Chan \& Reich, 2007; Wessels \& Loggerenberg, 2006). Many have analyzed IT governance practices (e.g., mechanisms and models) in the public sector, including their influence on effective IT governance (Martin et al., 2005; Warland \& Ridley, 2005; Ali \& Green, 2007; Jansen \& Tranvik, 2011). Others have identified the necessary conditions, including the critical factors of success for effective IT governance in the public sector (Weill \& Ross, 2004; Tan et al., 2007; Nfuka \& Rusu, 2010, Kurti et al., 2014).

Most current research on IT governance is at the strategic level, whereas tactical and operational levels have been explored by a limited number of studies. Different authors have also recognized the importance of these levels for achieving strategic alignment, which is considered the goal of IT governance (Gutierrez \& Serrano, 2007; De Haes \& Van Grembergen, 2005). There is no doubt that the senior managers are the most informed participants in the organizations and their involvement and support are essential for effective IT governance (Teo \& Ang, 1999; Luftman et al., 1999; Weill, 2004). However, IT governance is required at all levels of the organization for proper alignment of

\footnotetext{
${ }^{1}$ University of Tirana, Faculty of Economy, ezmolda.barolli@unitir.edu.al

${ }^{2}$ Keminet, Tirana, Albania, ilir.kurti@keminet.net
} 
business with IT. This is achieved by introducing and translating the business and IT objectives into actions for people at every level of the organization (Weill, 2004; ITGI, 2003; Guldentops, 2004b). Gutierrez and Lycett (2011) argue that these are the views of the mid- and low-level managers who explain the problems and challenges of people in the day-to-day implementation of strategies. They suggest that, a better understanding of how managers at different organizational levels view IT governance would minimize the differences between them and lead to improved IT governance.

Moreover, Kurti et al. (2014) noted that most studies relating to IT governance use an isolationist approach, examining only specific aspects. To reduce this gap in knowledge, they proposed a new construct that considered different dimensions of IT governance. Their construct considers both the lifecycle and the desired output of IT governance. The lifecycle involves focus areas defined by the IT Governance Institute (ITGI), whereas the desired output represents the business and IT alignment.

In line with the suggestion of Gutierrez and Lycett (2011), the purpose of this present study is to present a novel construct to help analyze and improve current understanding of the differences between managers at various organizational levels.

\section{Literature Review}

With the advent of the 21st century, information technology has become essential for business growth and sustainability. Digitalization of 'virtually everything' has profoundly impacted organizations' business models and processes. This nexus of information technology has placed IT governance at the spearhead of business imperatives. The governance of IT is a top management priority, being ranked as the single most important factor for generating business value from IT (Weill \& Ross, 2004).

The governance of IT embeds varying disciplines. Therefore, multiple definitions have surfaced from different perspectives (ITGI, 2003; Weill, 2004; Webb et al., 2006). Nevertheless, each, at their core, have IT governance definitions that emphasize the rights and responsibilities of decisions related to IT. The Strategic Alignment Model (Henderson \& Venkatraman, 1991) is the most used model in the study of IT governance. However, other alternatives include the Strength, Weakness, Opportunities, and Threats, (SWOT) analysis (Rowe, 1996), the Critical Success Factors (CSFs; Rockart 1979), the IT Balanced Scorecard (Van Grembergen \& Van Bruggen, 1997), Information Economics (Parker et al., 1988), and the Scenario Analysis (Galliers, 1993).

Most research on effective IT governance considers only the specific aspects (Buckby et al., 2009). This 'divide-and-conquer' approach predominates the problem-solving strategy in both business and information systems communities. Nonetheless, slicing the problem into smaller pieces and solving each one separately fails to address the complete problem (Peterson, 2004). Adoption of a holistic approach to IT governance recognizes its complex and dynamic nature (De Haes \& Van Grembergen, 2009).

Bearing in mind such concerns, Kurti et al. (2014) suggested a new construct to study IT governance. Their proposal combines two important aspects of IT governance that offer a more comprehensive view. The first one examines IT governance along five focus areas, defined by ITGI. These include 1) strategic alignment, 2) value delivery, 3) risk management, 4) resource management, and 5) performance measurement. This view placed IT governance lifecycle at the forefront. Typically, the first step is to align business with an IT strategy and then implement the delivery of a promised value. This requires careful management of resources and mitigation of associated risks. Finally, maintaining the alignment requires a periodic assessment of strategy and continuous measurement of performance.

The lifecycle of IT governance is not an isolated business case. It is widely accepted that the goal of an effective IT governance is to align business with IT (De Haes \& Van Grembergen, 2005). Examining the literature on business and IT alignment, Schlosser et al. (2012) outlined the dimensions that bound present conceptualizations of the alignment to the construct. They argued that dimensions exposed in the current research were non-selective and partly confusing. Hence, they proposed using three dimensions to frame the content of alignment. More specifically, they proposed human, social, and intellectual dimensions. This comprises the second component of the construct by Kurti et al. (2014; Table 1). The construct was validated by analyzing CSFs for effective IT governance. The CSFs method was chosen because of its simplicity and practical usage in identifying the few areas of activity where the management needed to constantly focus (Rockart, 1979). 


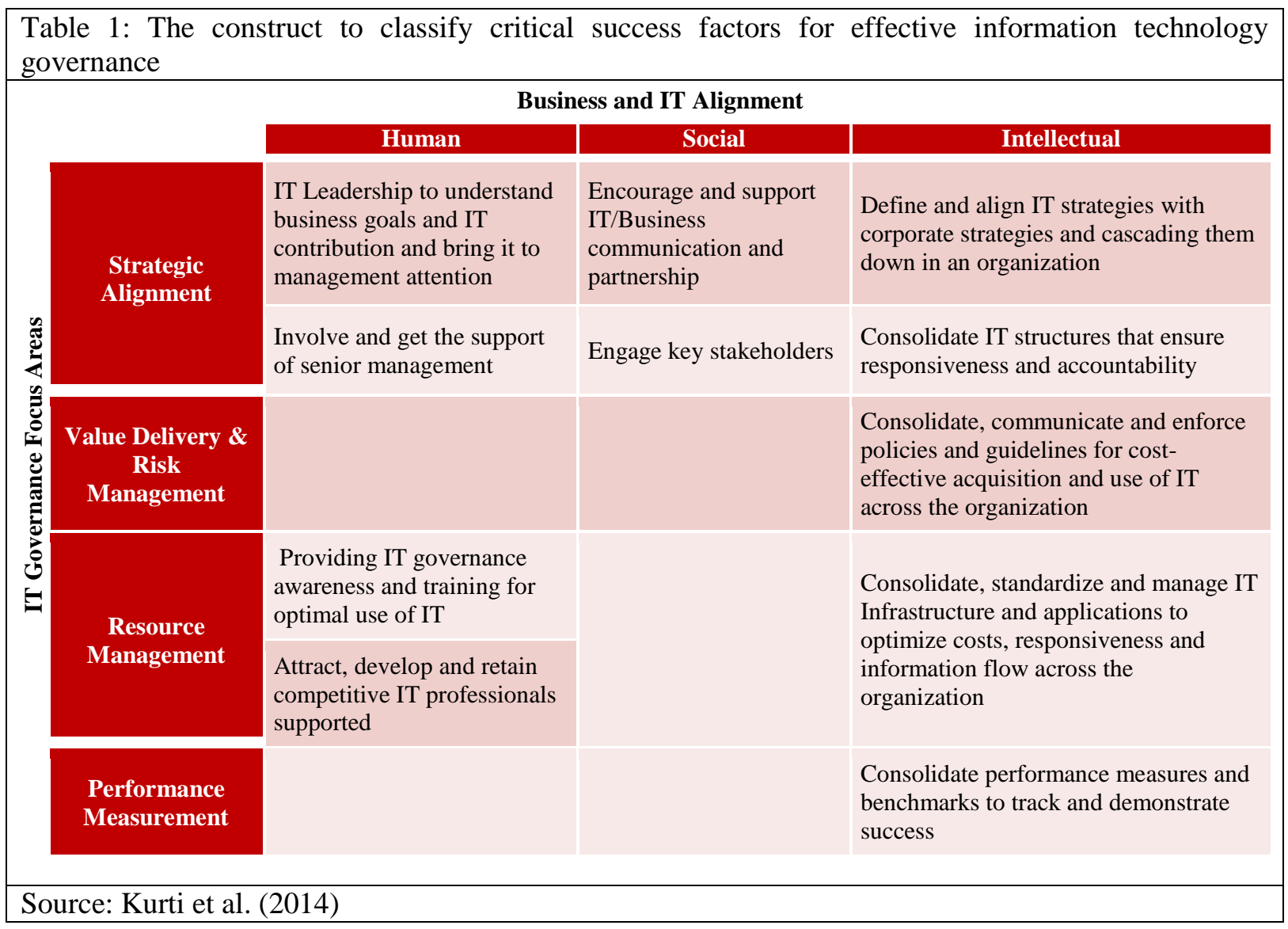

According to the ITGI, the primary concerns of IT governance are its delivery of business value and the mitigation of IT risks. The first has the main pillar of IT and business strategic alignment, whereas the second promotes the introduction of accountability in corporations. Adequate resources and continuous measurement are essential for obtaining results. The governance of IT is an integral part of overall corporate governance and usually occurs at all layers of the organization. Team leaders report to and receive direction from their managers, the managers report up to the executive, and the executive reports to the board of directors. Reports that indicate deviation from targets will usually include recommendations for actions endorsed by the governing layer (ITGI, 2003).

Previous research on IT governance has focused mainly on the views of top-level executives. Power (2006) explains that the differences in perceptions between managers at different levels of organization can be a problem for adopting technological innovations. Gutierrez et al. (2011) reported that despite the support of senior managers, IT projects continue to fail during their implementation. They argue that the formulation of an IT project at the strategic level can align with company goals, but during the implementation, as it spreads down the organizational levels, the original objectives are lost. Clearly, IT governance will not be effective unless the strategy and goals are cascaded through the organization to the lowest level (ITGI, 2003).

The research of business and IT alignment has progressed in the last three decades (Walentowitz, 2012). Schlosser et al. (2012) found that the literature on strategic level alignment was rather advanced. However, they called on future studies to focus research efforts at the implementation of alignment at non-strategic levels. Furthermore, they recommended an increased focus on studying the informal aspects of alignment ('soft' factors like cognitive linkages and shared understanding), which are less researched then formal ones (strategies, plans, and committees). Chen (2010) also agrees that alignment needs to be addressed at different levels: strategically through IT needs, projected in the future, tactically through adequate resource allocation, and operationally through effective and efficient operations within the IT department. On the necessity of alignment at the operational and tactical level, Tarafdar and Qrunfleh (2009) argued that it ensures applications are successfully implemented, maintained, and used in accordance with the business needs. 
Although there exist various IT alignment models, little is known about the impact of factors affecting the alignment across different organizational levels (Gutierrez et al., 2011). To fill this gap in knowledge, a new construct is proposed (Figure 1). The validity of this construct is tested by exploring CSFs for effective IT governance in the Albanian public sector. Critical success factors have been widely researched (Tan et al., 2007) and adapted from different perspectives (Esteves de Sousa, 2004). The purpose of this study is to provide a model that both practitioners and researchers can use to help lower the disparities between managers at different levels. From a researcher's point of view, it provides a foundation for further study in using a different approach towards IT governance.

\section{Data and Methodology}

The research methodology used in this study is based on the work of Kurti et al. (2014). This study extended the construct of Kurti et. al (2014; Table 1) by adding a third axis to cover the organizational levels (Figure 1) and retaining the holistic view of IT governance. The applicability of the construct was supported by investigating the CSFs for effective IT governance. The study aimed to reveal how the CSFs for effective IT governance were viewed within the different levels of the Albanian publicsector organizations.

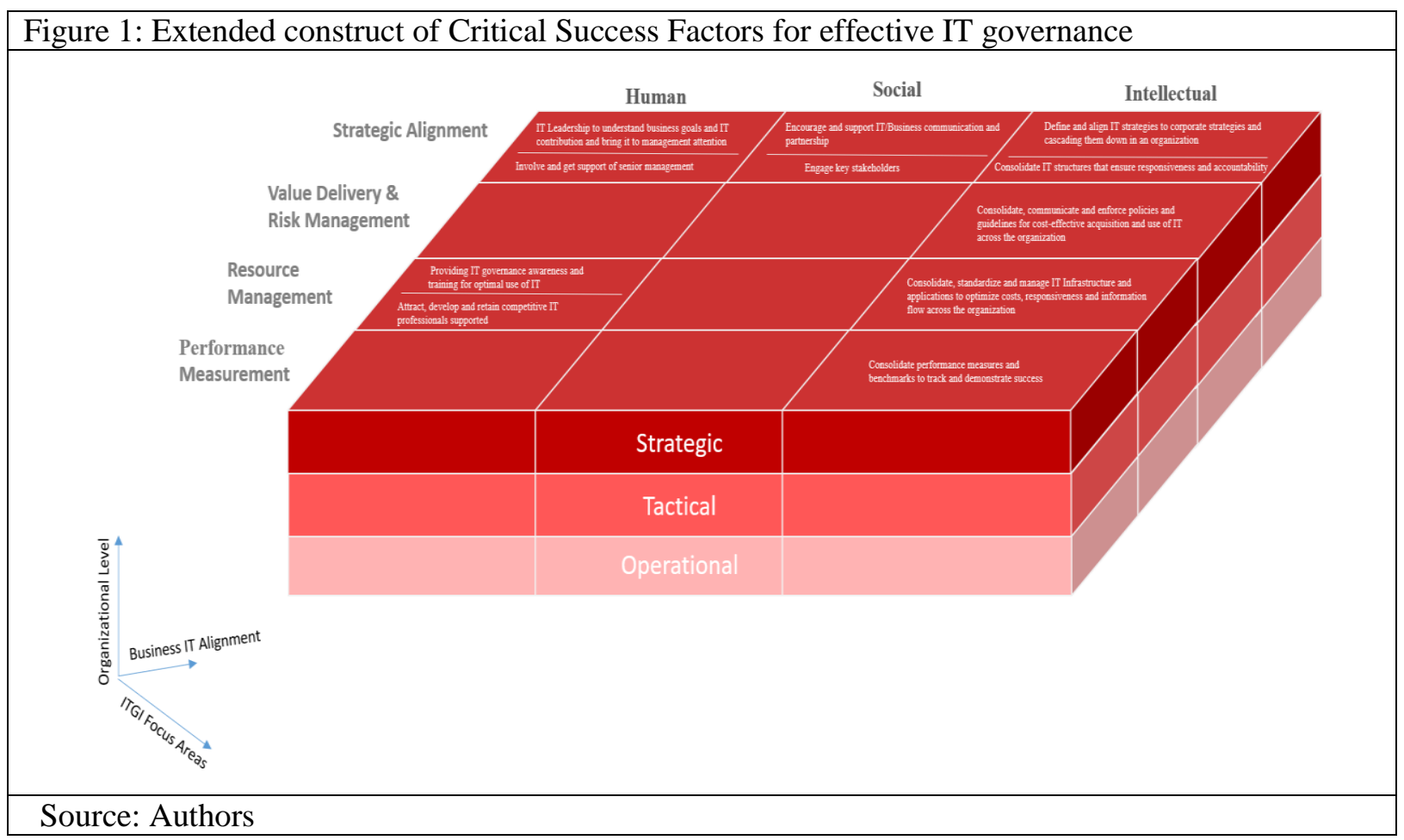

The study was a case study, as defined by Yin (2003), and structured interviews were based on qualitative strategies of Myers (1997). Data were analyzed according to the methods of Lewis-Beck (1995). The data on the Albanian public sector were collected from five public sector organizations, that were chosen based on their organization-wide use of IT. The number of participants was 61, representing three-organization levels: strategic, tactic, and operational (Table 2).

Table 2: Selected organizations and participant numbers for the case study

\begin{tabular}{|l|c|c|c|c|}
\hline Organization Name & Strategic & Tactical & Operational & Total \\
\hline Ministry of Defense & 3 & 9 & 8 & 20 \\
\hline General Directorate of Taxation & 3 & 5 & 6 & 14 \\
\hline Ministry of Finance & 2 & 2 & 4 & 8 \\
\hline Ministry of Justice & 2 & 4 & 4 & 10 \\
\hline Ministry of Health & 2 & 3 & 4 & 9 \\
\hline Total & $\mathbf{1 2}$ & $\mathbf{2 3}$ & $\mathbf{2 6}$ & $\mathbf{6 1}$ \\
\hline
\end{tabular}

Source: Authors 
The schema of Gutierrez et al. (2011) was used to classify the participants into the three categories:

1. Strategic. The strategic level category included participants who aligned closest with the organization strategy and had a director or head positions in the organization or business unit level.

2. Tactical. Participants in charge of the strategy implementation with the director or head positions within the sub-business unit were selected for this category.

3. Operational. This category included managers who were assigned to the detailed projects. Their positions varied from project and IT managers to senior IT developer, product manager, customer service manager, and project sponsor.

The initial list of 11 Critical Success Factors for effective IT governance was identified from Nfuka and Rusu (2010; Table 3).

\begin{tabular}{|l|l|}
\hline Table 3: List of Critical Success Factors for effective governance \\
\hline Code & Critical Success Factor \\
\hline FKS 1 & $\begin{array}{l}\text { Consolidate, standardize and manage IT Infrastructure and applications to optimize costs, responsiveness and } \\
\text { information flow across the organization }\end{array}$ \\
\hline FKS 2 & IT Leadership to understand business goals and IT contribution and bring it to management attention \\
\hline FKS 3 & Providing IT governance awareness and training for optimal use of IT \\
\hline FKS 4 & $\begin{array}{l}\text { Consolidate, communicate and enforce policies and guidelines for cost-effective acquisition and use of IT } \\
\text { across the organization }\end{array}$ \\
\hline FKS 5 & Encourage and support IT/Business communication and partnership \\
\hline FKS 6 & Involve and get the support of senior management \\
\hline FKS 7 & Attract, develop and retain competitive IT professionals supported \\
\hline FKS 8 & Consolidate IT structures that ensure responsiveness and accountability \\
\hline FKS 9 & Engage key stakeholders \\
\hline FKS 10 & Define and align IT strategies with corporate strategies and cascading them down in an organization \\
\hline FKS 11 & Consolidate performance measures and benchmarks to track and demonstrate success \\
\hline Source: Nfuka and Rusu (2010) \\
\hline
\end{tabular}

Using the methods of Kurti et. al (2014), the list of CSFs was transformed into a questionnaire for face-to-face interviews. Sixty-one participants, representing both business and IT at different organization levels (Table 2), were interviewed. Considering the suggestion of Pinto and Mantel (1990) that some factors can have a greater influence on success than others the respondents were asked to rate the importance of each CSF in regards to their organization. The results were captured using a five-point Likert scale (5 for 'very important'; 4 for 'important'; 3 for 'a little'; 2 for 'not important at all', and 1 for 'I do not know'). Additionally, it was made clear to respondents that the list of CSFs was neither exhaustive nor fixed and they were encouraged to add comments about missing CSFs. This approach aimed to avoid biased answers that may have resulted from the suggested responses (Foddy, 1994).

The CSFs were ranked based on the percentage of survey responses specifying a particular CSF as effective IT governance. This meant that a respondent marked the CSF to be 'important' or 'very important' for effective IT governance in their organization.

The limitations of this study were the small sample size and the limited number of organizations, which prevented the application of more complex techniques on the data collected. Hence, caution is recommended in interpreting and generalizing the results of this study.

\section{Results and Discussion}

Figure 2 shows that, at a strategic level, four critical success factors displayed the same result (83.33\%). These were (1) consolidate, standardize and manage IT Infrastructure and applications to optimize costs, responsiveness, and information flow across the organization, (2) providing IT governance awareness and training for optimal use of IT, (3) encourage and support IT or business communication and partnership, and (4) define and align IT strategies to corporate strategies and 
cascading them down in an organization. Projecting these results onto the axis of the construct formed in this study showed that the intellectual dimension was the highest-ranked dimension (two of four CSFs are in this dimension). Moving the perspective onto IT governance lifecycle axis the results at the strategic level showed the areas focusing on strategic alignment and resource management ranked with the same importance. Each of those areas was represented by two CSFs.

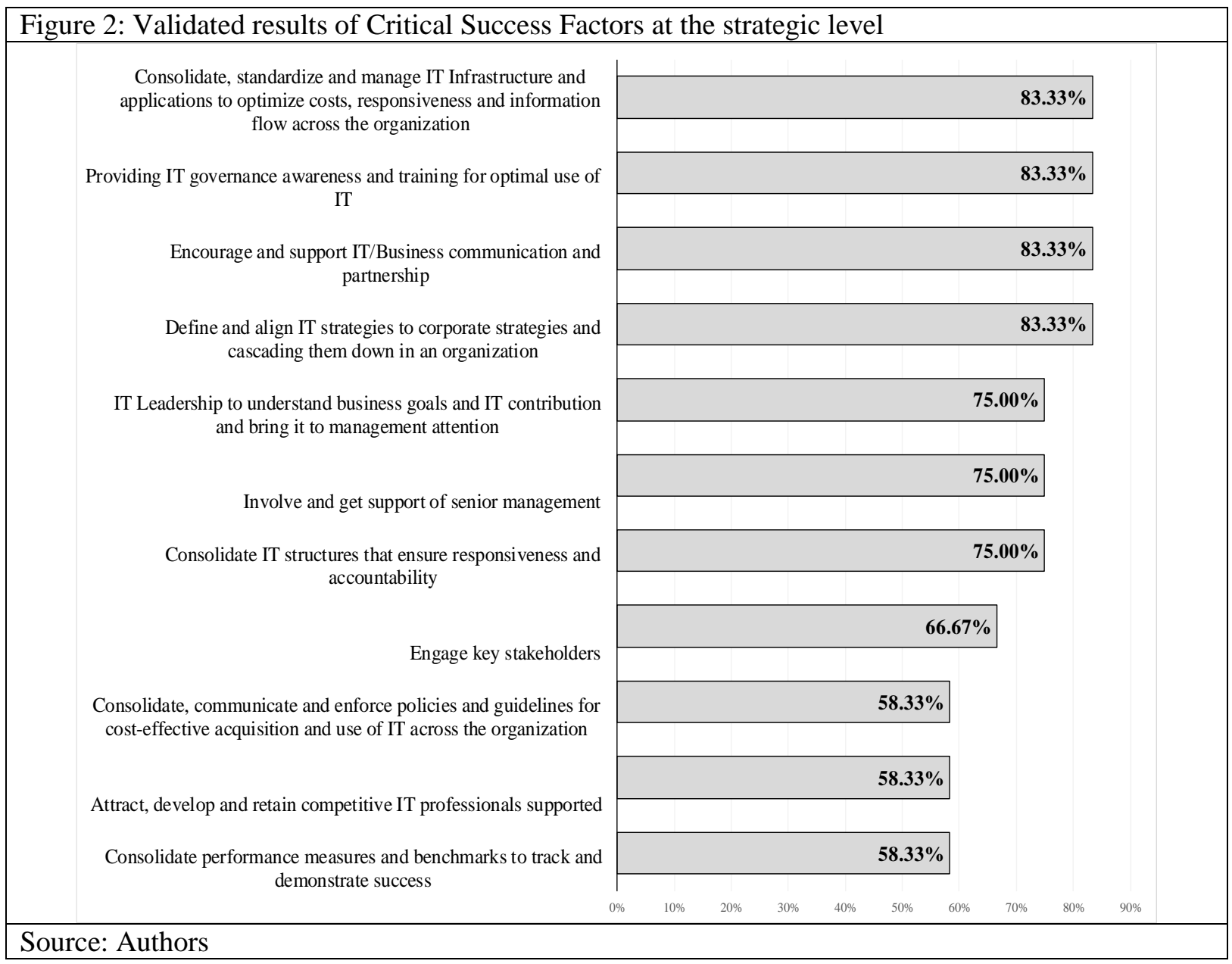

Stepping down to the tactical level, results show that participants at this level continued at the forefront of the intellectual dimension (two of first three CSFs were from this dimension; Figure 3). While the concerns about infrastructure consolidation and cost optimization at this level were the same as at the strategic level, participants at this level were also greatly concerned about performance management. Using the IT governance lifecycle viewpoints, results at the tactical level on this axis were more balanced than those of the strategic one. Although the most important area at the tactical level was resource management, the management at this level also gave a great deal of attention to strategic alignment and performance management focus areas.

Dividing operational level results according to the IT governance lifecycle axis, the outcome was similar to that at the strategic level (Figure 4). Participants at this level also considered the intellectual dimension at the top of their priorities (two of the first four CSFs belonged to this dimension). The same remained true on changing the focus on results through the ITGI defined focus areas. Similar to the strategic level, the focus of participants at the operational level was on resource management and strategic alignment. However, contrary to the strategic level, the CSFs for the operational level featured more strategic alignment types than those for resource management.

The overall results show that in Albanian public-sector institutions, respondents at all three organizational levels viewed resource management as a top priority (Table 4). The business value of IT, which is promoted through effective IT governance (Van Grembergen et al., 2004), according to Melville et al. (2004), is dependent on IT resources. Moreover, the amplified presence of problems, 


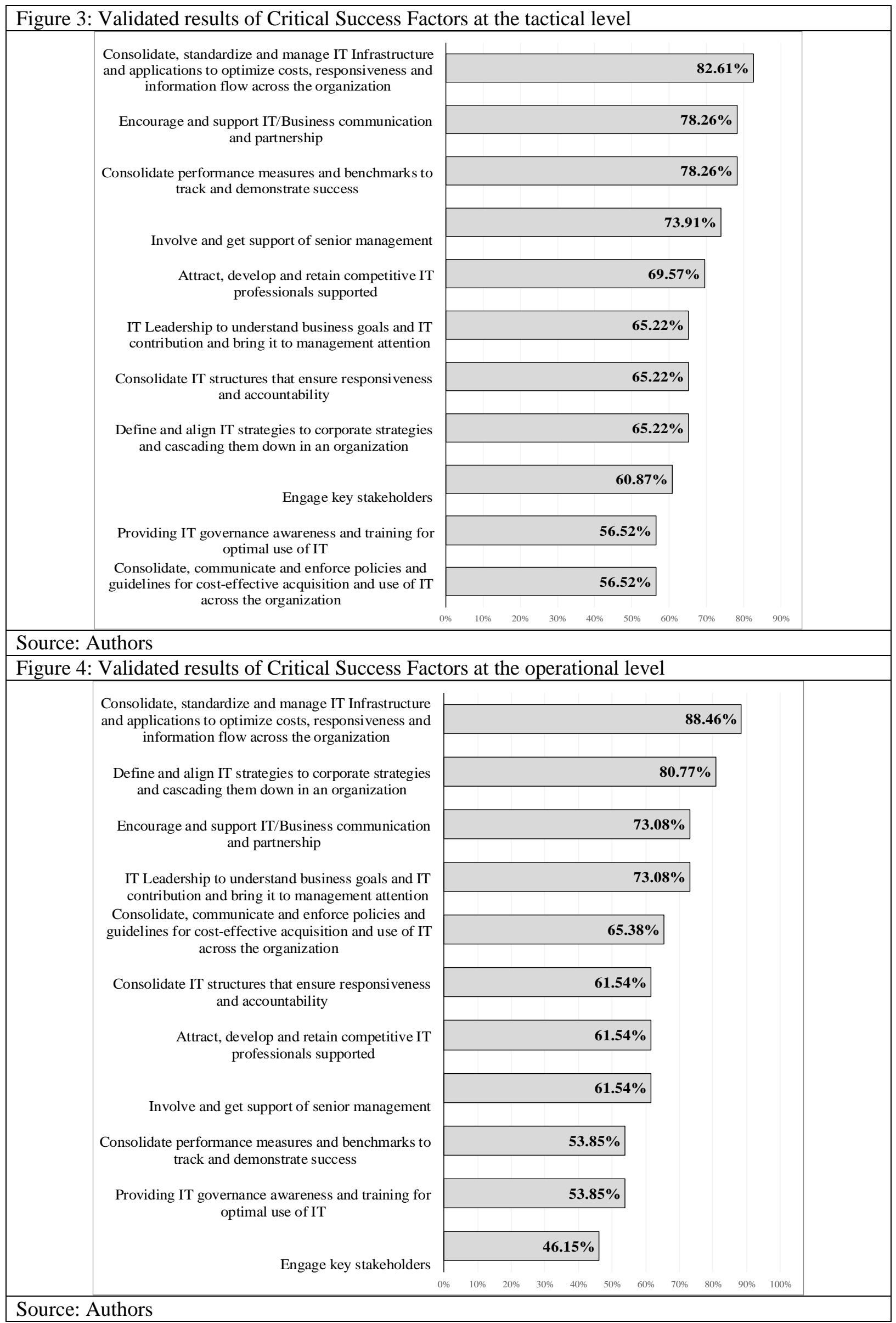


such as fragmented IT initiatives, loss of synergies and a relatively lower rate in effective use of IT assets in developing countries, have been continually featured in literature (Ndou, 2004; Kromidha \& Cordoba-Pachón, 2010; Yahya, 1993; Bakari, 2007; Nfuka \& Rusu, 2010). Kurti et al. (2014) argue that IT departments are purely seen as service providers, which emphasizes the need to attribute an appropriate quality and cost to IT services (Weill \& Woerner 2009).

From the business and IT content viewpoint, the intellectual dimension has dominated the interest of all organizational levels within the Albanian public sector. This has included all formalized artifacts built or institutionalized by IT or business employees or both (Schlosser et al., 2012).

The governance of IT has remained a leading issue for both academics and practitioners over the past decade. The reason for the increased interest in IT governance is because IT governance is the single most important determinant in generating a business value from IT. It is important to note that all organizations have IT governance. Those with effective governance have actively designed a set of IT governance mechanisms to encourage behavior that is consistent with the organization's mission, strategy, values, norms, and culture (Weill \& Ross, 2004). The extension of the construct by Kurti et al. (2014) in this study provided an improved understanding of the dynamics affecting a successful implementation of IT governance. The extension added a new dimension to the original construct, namely the organizational levels of strategic, tactical, and operational. This supports earlier studies that had previously identified the importance of IT governance across all organizational levels (ITGI 2003; Power 2006; Tarafdar \& Qrunfleh 2009; Chen 2010; Gutierrez et al. 2011).

\begin{tabular}{|c|c|c|c|c|c|c|c|c|}
\hline Critical Success Factors & Dim & $\begin{array}{l}\text { Focus } \\
\text { Area }\end{array}$ & $\begin{array}{l}\text { Validatic } \\
\text { Strategic }\end{array}$ & & $\begin{array}{l}\text { Validati } \\
\text { Tactical }\end{array}$ & & $\begin{array}{l}\text { Validatic } \\
\text { Operatio }\end{array}$ & Lvl \\
\hline $\begin{array}{l}\text { Infrastructure and applications to optimize } \\
\text { costs, responsiveness and information flow } \\
\text { across the organization }\end{array}$ & I & $\mathrm{RM}$ & $83.33 \%$ & 4 & $82.61 \%$ & 1 & $88.46 \%$ & 1 \\
\hline $\begin{array}{l}\text { IT Leadership to understand business goals } \\
\text { and IT contribution and bring it to } \\
\text { management attention }\end{array}$ & $\mathrm{H}$ & SA & $75.00 \%$ & 7 & $65.22 \%$ & 8 & $73.08 \%$ & 4 \\
\hline $\begin{array}{l}\text { Providing IT governance awareness and } \\
\text { training for optimal use of IT }\end{array}$ & $\mathrm{H}$ & $\mathrm{RM}$ & $83.33 \%$ & 3 & $56.52 \%$ & 11 & $53.85 \%$ & 10 \\
\hline $\begin{array}{l}\text { Consolidate, communicate and enforce policies } \\
\text { and guidelines for cost-effective acquisition and } \\
\text { use of IT across the organization }\end{array}$ & I & $\begin{array}{l}\text { VD \& } \\
\text { Risk }\end{array}$ & $58.33 \%$ & 11 & $56.52 \%$ & 10 & $65.38 \%$ & 5 \\
\hline $\begin{array}{l}\text { Encourage and support IT/Business } \\
\text { communication and partnership }\end{array}$ & $\mathrm{S}$ & SA & $83.33 \%$ & 2 & $78.26 \%$ & 3 & $73.08 \%$ & 3 \\
\hline Involve and get support of senior management & $\mathrm{H}$ & SA & $75.00 \%$ & 6 & $73.91 \%$ & 4 & $61.54 \%$ & 8 \\
\hline $\begin{array}{l}\text { Attract, develop and retain competitive IT } \\
\text { professionals supported }\end{array}$ & $\mathrm{H}$ & $\mathrm{RM}$ & $58.33 \%$ & 10 & $69.57 \%$ & 5 & $61.54 \%$ & 7 \\
\hline $\begin{array}{l}\text { Consolidate IT structures that ensure } \\
\text { responsiveness and accountability }\end{array}$ & I & SA & $75.00 \%$ & 5 & $65.22 \%$ & 7 & $61.54 \%$ & 6 \\
\hline Engage key stakeholders & $\mathrm{S}$ & SA & $66.67 \%$ & 8 & $60.87 \%$ & 9 & $46.15 \%$ & 11 \\
\hline $\begin{array}{l}\text { Define and align IT strategies to corporate } \\
\text { strategies and cascading them down in an } \\
\text { organization }\end{array}$ & I & SA & $83.33 \%$ & 1 & $65.22 \%$ & 6 & $80.77 \%$ & 2 \\
\hline $\begin{array}{l}\text { Consolidate performance measures and } \\
\text { benchmarks to track and demonstrate success }\end{array}$ & I & $\mathrm{PM}$ & $58.33 \%$ & 9 & $78.26 \%$ & 2 & $53.85 \%$ & 9 \\
\hline \multicolumn{9}{|l|}{ Source: Authors } \\
\hline
\end{tabular}

The results from projecting the business and IT alignment axis suggest that participants at all three organizational levels had an increased focus on the intellectual dimension. A deeper analysis of this axis reveals that while at the strategic and tactical level human dimension is ranked highly, the same is not true at the operational level. One explanation for this difference is the varying perception of IT across the organizational levels. Staffs with strategic and tactical positions mostly view IT as a service. 
The dominant issue for staff at these levels was to have the appropriate technical people at the operational level so that IT issues would not be escalated and thus, sent to them. At the operational level, given the context of the public sector in a developing country, the main concern was to comply with the guidelines and formal procedures approved at the upper levels of the organization.

These findings were established by using the IT governance lifecycle axis as a third dimension for projecting the responses. At all levels, resource management was a central point. However, a wider assessment of the results reveals that, while the strategic level featured resource management and strategic alignment as prevalent areas of focus, the tactical and operational levels had other focus areas that were similarly featured. At the operational level, performance measurement appeared as a fundamental concern, whereas, at the tactical level, value delivery and risk management also emerged as important focus areas.

\section{Conclusion}

The results of this study may benefit both researchers and practitioners. First, the findings add to the current body of knowledge about IT governance. In particular, they improve the current understanding of the Critical Success Factors that help implement effective IT governance, especially from the perspective of IT governance in the developing countries. Second, the proposed construct may assist researchers to identify and steer towards less-explored topics in the field. Third, the results suggest that the instrument proposed in this study can provide a more granular view of the important areas for ensuring successful IT governance. In practice, the proposed construct offered a simple and intuitive tool to ease the identification of the few areas that were determined important for success. A threedimensional picture of these areas enable managers at all organizational levels to direct their attention and resources towards the appropriate direction. Finally, because of the small sample numbers of participants and organizations in this study, caution is needed in generalizing these results. Given the limited research in this area and a lack of similar studies to compare the findings, further research of the topics in this paper is recommended. Using the construct proposed in this paper to gain insights into the structures, processes, and relational mechanisms that enable effective IT governance supports such future research.

\section{References}

Ali, S., \& Green, P., (2007). IT Governance Mechanisms in Public Sector Organisations: An Australian Context. (F. B. Tan, Ed.) Journal of Global Information Management, 15(4).

Bakari, J. K., (2007). A Holistic Approach to Managing ICT Security in Non-Commercial Organizations: A Case Study in a Developing Country. Doctoral Thesis. Stockholm: Stockholm University.

Brown, C. V., (1997). Examining the Emergence of Hybrid IS governance Solutions: Evidence from a Single Case Site. Information Systems Research, 8(1), 69-95.

Brown, A. E., \& Grant, G. G., (2005). Framing the Framework: A Review of IT Governance Research. Communications of the Association for Information Systems, 15, 696-712.

Buckby, S., Best, P., \& Stewart, J., (2009). The Current State of Information Technology Governance Literature. In A. CaterSteel (Ed.), Information Technology Governance and Service Management: Frameworks and Adaptations (pp. 1-43). Hershey, New York: IGI Global.

Chan, Y. E., \& Reich, B. H., (2007). IT alignment: what have we learned? Journal of Information Technology, 297-315.

Chen, L., 2010. Business-IT alignment maturity of companies in China. Information \& Management, 47(1), 9-16. doi:10.1016/j.im.2009.09.003

De Haes, S. \& Van Grembergen, W., (2009). An Exploratory Study into IT Governance Implementations and its Impact on Business/IT Alignment. Information Systems Management, 26(2), pp.123-137

De Haes, S. \& Van Grembergen, W., (2005). IT Governance Structures, Processes, and Relational Mechanisms: Achieving IT/Business Alignment in a Major Belgian Financial Group. In Proceedings of the 38th Annual Hawaii International Conference on System Sciences. IEEE, p. 237b.

Duffy, J., (2002). IT Governance and business value part 1: IT Governance - An issue of critical importance. IDC document, nr. 27291.

Esteves de Sousa, J.M., (2004). Definition And Analysis Of Critical Success Factors For ERP Implementation Projects. Universitat Politècnica de Catalunya, Barcelona, Spain.

Foddy, W., (1994). Constructing Questions for Interviews and Questionnaires: Theory and Practice in Social Research. Cambridge University Press.

Galliers, R. D., (1993). Towards a flexible information architecture: integrating business strategies, information systems strategies and business process redesign. Information Systems Journal, 3(3), 199-213. 
Guldentops, E., (2004a). Governing Information Technology through COBIT. In W. Van Grembergen, ed. Strategies for Information Technology Governance. Idea Grup Publishing, pp. 269-309.

Guldentops, E., (2004b). Key Success Factors for Implementing IT Governance, Let's Not Wait for Regulators to Tell Us What to Do. Information Systems Control Journal, 2(1), pp.22-24.

Gutierrez, A., \& Lycett, M., (2011). IS Alignment Factors: Dynamic Relationships At Strategic, Tactical and Operational Level. UK Academy for Information Systems Conference Proceedings 2011. Paper 19.

Gutierrez, A., \& Serrano, A., (2007). Assessing strategic, tactical and operational alignment factors for SMEs: alignment across the organisation's value chain. International Journal of Value Chain Management, 2(1), 33-56.

ITGI, 2003. Board Briefing on IT Governance, 2nd Ed. IT Governance Institute.

Jansen, A., \& Tranvik, T., (2011). The State of IT Governance: Patterns of Variation at the Central Government. Proceedings of the 10th IFIP WG 8.5 international conference on Electronic government. Springer Berlin / Heidelberg.

Kromidha, E., \& Córdoba-Pachón, J. R., (2010). E-Government and Its Evaluation in South East Europe: The Case of Albania. In J. R. Cordoba-Pachón, \& A. E. Ochoa-Arias (Eds.), Systems thinking and e-participation: ICT in the governance of society (pp. 260-275).

Kurti, I., Barolli, E., Sevrani, K., (2014). Effective IT Governance in the Albanian Public Sector - A Critical Success Factors Approach, The Electronic Journal of Information Systems in Developing Countries, Vol. No. 63 (6), 2014, pp 1-22.

Lewis-Beck, M.S., 1995. Data Analysis: An Introduction, Sage Publications.

Loh, L., \& Venkatraman, N., (1992). Diffusion of Information Technology Outsourcing: Influence Sources and the Kodak Effect. Information Systems Research, 334-359.

Luftman, J. \& Ben-Zvi, T., (2011). Key Issues for IT Executives 2011: Cautious Optimism in Uncertain Economic Times. MIS Quarterly Executive, 10, pp.203-212.

Luftman, J. N., Papp, R., \& Brier, T., (1999). Enablers and Inhibitors of Business and ITAlignment. Communications of AIS, 1 .

Helbig, N., Hrdinová, J. \& Canestraro, D.S., (2009). Enterprise IT governance at the state level: An emerging picture. In Proceedings of the 10th Annual International Conference on Digital Government Research: Social Networks: Making Connections between Citizens, Data and Government. pp. 172-179.

Henderson, J.C. \& Venkatraman, N., (1991). Understanding strategic alignment. Business Quarterly, 55(3), pp.72-78.

Martin, N., Gregor, S., \& Hart, D., (2005). The social dimensions of business and IS/IT alignment: case studies of six public sector organizations. Australian Accounting Review, 15(3), 28-38.

Melville, N., Kraemer, K.L. \& Gurbaxani, V., (2004). Review: Information Technology and Organizational Performance: An Integrative Model of IT Business Value. MIS Quarterly, 28(2), pp.283-322.

Myers, M.D., (1997). Qualitative Research in Information Systems. MIS Quarterly, 21(2), p.241.

Ndou, V., (2004). e-Government for Developing Countries: Opportunities and Challenges. The Electronic Journal on Information Systems in Developing Countries, 18(1), 1-24.

Nfuka, E. N., (2012). IT governance in Tanzanian public sector organisations. Stockholm University, Faculty of Social Sciences, Department of Computer and Systems Sciences. Stockholm: Department of Computer and Systems Sciences.

Nfuka, E. N., \& Rusu, L., (2010). Critical Success Factors for Effective IT Governance in the Public Sector Organisations in a Developing Country: The Case of Tanzania. 18th European Conference on Information Systems (ECIS 2010). Pretoria, South Africa.

Nickels, D.W., (2004). Business and IT Alignment: What We Know That We Still Don't Know. In Proceedings of the 7th Annual Conference of the Southern Association for Information Systems. pp. 79-84.

Parker, M. M., Benson, R. J., \& Trainor, H. E., (1988). Information Economics: Linking Business Performance to Information Technology. Englewood Cliffs: Prentice-Hall.

Peppard, J., \& Ward, J., (2004). Beyond strategic information systems: towards an IS capability. Journal of Strategic Information Systems, 13, 167-194.

Peterson, R. R., (2004). Integration Strategies and Tactics for Information Technology Governance. In W. Van Grembergen (Ed.), Strategies for Information Technology Governance (pp. 37-80). Idea Group Inc.

Pinto, J. K. \& Mantel, S. J., (1990). The causes of project failure. IEEE Transactions on Engineering Management, 37(4), pp. 269-276.

Potnis, D.D., (2010). Measuring e-Governance as an innovation in the public sector. Government Information Quarterly, 27(1), pp.41-48.

Powell, T. C., \& Dent-Micallef, A., (1997). Information Technology as Competitive Advantage: The Role of Human, Business and Technology Resources. Strategic Management Journal, 18(5), 375-405.

Power, D. (2006). "Adoption of supply chain management-enabling technologies in SMEs: the view from the top vs. the view from the middle", Int. J. Value Chain Management, vol. 1, no. 1, pp. 64-93.

Rowe, A.J., (1996). Strategic management: A methodological approach, Reading, Massachusetts: Addison-Wesley. Rockart, J.F., (1979). Chief executives define their own data needs. Harvard business review, 57(2), pp.81-93. 
Sambamurthy, V., \& Zmud, R. W., (1999). Arrangements for Information Technology governance: A Theory of Multiple Contingencies. MIS Quarterly, 23(2), 261-291.

Tarafdar, M. and Qrunfleh, S., (2009). IT-Business Alignment: A Two-Level Analysis. ISM, Vol. 26, No. 4, pp. 338-349

Schlosser, F., Wagner, H. T. \& Coltman, T., (2012). Reconsidering the Dimensions of Business and ITAlignment. In 2012 45th Hawaii International Conference on System Sciences. IEEE, pp. 5053-5061.

Tan, W. G., Cater-Steel, A., Toleman, M., \& Seaniger, R., (2007). Implementing Centralised IT Service Management: Drawing Lessons from the Public Sector. ACIS 2007 Proceedings, (p. Paper 94.)

Teo, T. S., \& Ang, J. S., (1999). Critical success factors in the alignment of IS plans with business plans. International Journal of Information Management, 19, 173-185.

Van Grembergen, W. \& Van Bruggen, R., (1997). Measuring and improving corporate information technology through the balanced scorecard technique. In Proceedings of the 4th European Conference on the Evaluation of Information Technology (ECITE). pp. 1-18.

Van Grembergen, W., De Haes, S. \& Guldentops, E., (2004). Structures, Processes and Relational Mechanisms for IT Governance. In W. Van Grembergen, ed. Strategies for Information Technology Governance. Idea Grup Publishing, pp. 136.

Van der Zee, J. T., \& De Jong, B., (1999). Alignment is not enough: integrating business and information technology management with the balanced business scorecard. Journal of Management Information Systems, 16(2), 137 - 156.

Walentowitz, K., (2012). Aligning Multiple Definitions of Alignment--A Literature Review, 45th Hawaii International Conference on System Sciences, Maui, HI, 2012, pp. 4962-4971.

Warland, C., \& Ridley, G. (Eds.)., (2005). Awareness of IT Control Frameworks in an Australian State Government: A Qualitative Case Study. Proceedings of the 38th Annual Hawaii International Conference on System Sciences (p. 236b). IEEE Computer Society.

Webb, P., Pollard, C. \& Ridley, G., (2006). Attempting to Define IT Governance: Wisdom or Folly? In Proceedings of the 39th Annual Hawaii International Conference on System Sciences (HICSS'06). IEEE, p. 194a.

Weill, P., (2004). Don't Just Lead, Govern: How Top-Performing Firms Govern IT. MIS Quarterly Executive, 3(1), 1-17.

Weill, P., \& Ross, J. W., (2004). IT Governance: How top performers manage IT decision rights for superior results. Harvard Business School Press.

Weill, P., \& Woerner, S. L., (2009). The Future of CIO. MIT Sloan CISR Research Briefing, 9(1).

Wessels, E. \& Loggerenberg, J. Van, (2006). IT Governance: Theory and Practice. Proceedings of the Conference on Information Technology in Tertiary Education, (September), pp.18-20.

Yahya, A.H., (1993). On the problems of information technology management in developing nations. In Proceedings of the 1993 conference on Computer personnel research - SIGCPR '93. New York, New York, USA: ACM Press, pp. 349-355.

Yin, R.K. (2003) Case Study Research, Design \& Methods 3rd ed., Thousand Oaks, California: Sage Publications. 